\title{
Determinants of Economic Growth in Southern Africa Development Community: The Role of Institutions
}

\author{
Strike Mbulawa ${ }^{1}$ \\ ${ }^{1}$ Botho University, Faculty of Business and Accounting, Gaborone, Botswana \\ Correspondence: Strike Mbulawa, Botho University, Faculty of Business and Accounting, Gaborone, Botswana.
}

Received:March 17, 2015

Accepted:March 30, 2015

Available online: April 21, 2015

doi:10.11114/aef.v2i2.782

URL: http://dx.doi.org/10.11114/aef.v2i2.782

\begin{abstract}
The study focuses on economic growth in SADC by examining the role of institutional variables; determining the key drivers and finding out the strength of the marginal effects of institutional quality. The study used a GMM estimator by Arellano and Bond (1991) and annual country data covering the period 1996-2010. Good quality institutions have an indirect impact on growth by working through trade openness, gross fixed capital formation, financial openness, human capital and savings ratio. Government stability, improved government effectiveness and absence of conflicts have direct effect on economic growth. High inflows of foreign direct investment are beneficial in the presence of low levels of political violence. The generic determinants of economic growth are necessary but not sufficient in explaining economic growth. Thus any reforms meant to enhance economic growth in SADC should give priority to putting in place good quality institutions which are a vital precondition.
\end{abstract}

Keywords: Economic growth, Institutions, Panel data, SADC

\section{Introduction}

\subsection{Background to the Problem}

The discussions on economic growth, in literature, have been focusing on mainly two growth theories advocating for growth which is led by the accumulation of both physical and human capital. Theoretical works focusing on the determinants of growth include Solow (1956), Romer (1990), Barro (1991) and Barro and Sala-i-Martin (2004). Empirical works have focused on the aspects of growth at country level while cross country studies are still rare. Research work on linkages between growth and its various determinants is still inconclusive which is evidenced by the different theories of growth that have failed to agree on the drivers of growth.

However attention is now focusing on the contribution made by quality of institutions to economic growth. Institutions are comprised of formal and informal constraints like cultural norms and particular organizational structures covering common law, Lal (1998). They are constraints devised by humans that structure political and social interactions. Informal constraints comprise of sanctions, customs, traditions and codes of conduct while formal rules comprise of constitutions, laws and property rights, North (1990). They are guidelines upon which members of a society interact and shape the behavior of economic agents. Failure to follow these guidelines gives rise to economic ills like corruption, lack of respect of property rights, lack of government effectiveness and collapse in regulation which may adversely affect the allocation of resources and economic growth. The role of institutions on their influence on the decisions made by investors to put resources into beneficial economic projects has been explained by Acemoglu et al (2001) and Rodrik et al (2004), Glaeser et al (2004), Sala-i-Martin (2002). Political systems, for example, influence economic performance in democratic environments which also affect the regulation of economic activities and later on growth. The removal of political impediments creates a better business environment which supports stronger growth potential. The role of institutions on growth has recently shifted the direction of policy at country, regional and international levels. The study takes a closer look on the strength of the relationship between growth and quality of institutions at regional level.

The Southern Africa Development Community (SADC) comprises of 15 countries being middle income (South Africa, Namibia, Botswana, Mauritius and Swaziland), low income (Madagascar, Malawi, Mozambique, Tanzania and Zambia) and fragile economies (Democratic Republic of Congo, Lesotho \& Zimbabwe) and oil exporting (Angola). The majority are land locked, with narrow production bases, well endowed in natural resources, having agro-based economies and huge reliance on the clothing industry. One of the key initiatives for the regional bloc has been to make 
joint and supportive policies on attaining economic growth. The growth targets set out in regional indicative strategic development plan (RISDP) have not been attained which now call for conceited efforts to identify the drivers of growth. The growth rate in output has been erratic over the past decade which dampens the possibility of attaining the aims set out in the RISDP (see SADC (2011) for detailed survey). Attaining of these objectives cannot be possible by focusing only on standard determinants of growth in literature.

Literature shows that the strength of institutions is an important provision necessary for growth and studies on cross country level on the contribution of institutional factors on growth includes: Mauro (1995), Rodrik (1997), Julilian et al (2007) and Le (2008). This study was motivated first by the lack of consensus on the key drivers of economic growth in literature and secondly by the failure in literature to adequately capture the contribution made by institutional quality factors. Hassan et al (2011) shows that well-functioning financial systems are necessary but not sufficient for growth. The role of Institutions in fostering growth is still not fully explained by standard growth models hence the connection between the quality of institutions and economic growth still needs attention. This paper makes a contribution to the current debate by using a regional approach and employing the individual institutional variables as opposed to the widely used composite institutional measures. Specifically the study looks at the following questions:

- What are the key drivers of economic growth in the SADC region?

- Is the strength of institutions a vital precondition for economic growth in SADC?

- How do institutional factors explain economic growth in SADC region? Is there a direct or indirect connection?

- How significant are the marginal effects of institutions on economic growth in the SADC region?

The rest of the paper is organized as follows: the next subsections under section 1 provide a detailed review of literature on economic growth, institutions and other determinants of growth, section 2 explains the data and methodology issues, section 3 presents and discusses the findings and section 4 provides the conclusions and policy issues.

\subsection{Review of Literature}

\subsubsection{Conceptual Framework}

Economic growth is driven by several factors being supported by different theoretical underpinnings. Growth can be motivated by the buildup and use of existing and new capital. Human capital is mobilized through formal education and/or training received while at work. This concurs with the endogenous growth model (Lucas (1988) gives detailed discussion) which purports that growth emanates from the accumulation of human capital and innovation. The free movements of human capital across boundaries generate spillover effects which increase the industries' ability to employ and increase the income generating capacity. Thus accumulation of human capital will in the long term generate growth. Solow's model in 1956 argues that growth is supported by investment (physical capital) which allows a country to follow a steady state growth path due to improvements in technology. When a country operates under autarky citizens are exposed a low quality of life but this changes upon removing the boundaries created by the production frontiers, (Adam Smith, 1776) and David Ricardo, 1951). The division of labor allowed producers to reduce production costs and remain competitive.

The main theories of growth fail to agree on the drivers of economic growth. There is a shift in literature from the standard models of growth due to the realization that institutional factors play a key role in driving economic growth, (see Acemoglu and Johnson, 2005 and Dixit, 2004 for detailed survey). Institutions should be considered by looking at a set of factors which are related to the way in which a society and an economy interact. The role of institutions is to account for factors related to the protection of property rights, enforcement of contracts, perceptions on how legal system can be predicted and be made effective, quality regulation, the transparency of governance and control of corruption, Sala-i-Martin (2002). The quality of institutions facilitates the efficient allocation of resources and effective decision making process which subsequently increase growth in the long term. The study gives an extensive discussion of institutional factors and other determinants of growth in the subsequent section.

\subsubsection{Empirical Review}

Significant strides have been made on the discussions on economic growth both in developed and developing nations using time series and panel data as well as firm level and country level data. Determinants identified in literature include: financial development, investment, inflation, trade openness, remittances, savings level, foreign direct investment and institutions. This paper examines the role of institutions in driving growth in a regional block which is not a new phenomenon though inconclusive. There are two strands of literature on institutions: the first advocates for the fact that institutional quality promotes growth while the second argues that it retards economic growth in the long term and discussions follow below.

Studies showed that good governance, institutional reforms and improvements in the educational system enhance levels 
in economic output and efficiency thus a country with better institutions experiences superior performance. A sound institutional framework is vital for financial development to have greater effects on economic growth thus an economy benefits more by developing stronger institutions. Good quality institutions should be supported by a large share of human capital in research and development, (Tebaldi and Elmslie, 2008; Gylfason and Hochreiter, 2008; Hill and Menon, 2013; Aron, 2000; Bhupatiraju and Verspagen, 2013). Poor countries are likely to suffer from low growth, even though there is more financial base, due to weak institutions. The rate of growth is lower during periods in which there are higher chances of government collapse, (Demetraides and Law, 2004 and Alesina et al, 1996). Some studies show that human capital is the driver of growth and not institutions and that there is little evidence of a robust negative connection between institutions and performance indicators, (Glaeser et al, 2004 and Commander and Nikoloski, 2010).

There are two schools of thought showing that corruption and economic growth have bidirectional causality and that corruption can be harmful (by increasing uncertainty, levels of inefficiencies in government expenditure, reducing investment in physical \& human capital, increasing political instability and the cost of doing business) to growth. The negative effect of corruption on growth can either be direct or indirect as it works through other variables but this can be reduced in countries with low governance levels and high degrees of regulation, (Acemoglu and Verdier, 1998; Mo, 2001; Venard, 2013; Asiedu and Freeman, 2009; Farida and Ahmadi-Esfahani, 2006; Hodge et al, 2009; Mauro, 2004; Aidt, 2009; Gyimah - Brempong, 2001). Some studies argue that corruption enhances growth through reducing government consumption, facilitating efficient processing of projects and increasing trade openness. It is the most significant determinant for investment growth in transition economies, (Goel, 2011; Heckelman and Powell, 2008 and Podobnik et al, 2008). Generally there is no consensus on the effect of corruption on growth for example Drury et al (2006) further showed that corruption has no significant effect on growth.

Growth is experienced where the voice of citizens positively influence the effectiveness of government, (Maria-Carmen, 2009 and Cooray, 2008). Papaconstantinou et al (2013) argues that bureaucracy together with corruption negatively affects growth but the causal relationship moves from corruption and bureaucracy to economic growth.

The impact of political regimes (democracies) on economic growth varies across countries as they survive in developed countries and they have no effect on investment and growth of total income. Evidence suggests that economic development and democracy have bidirectional causality, democracy has no direct effect on economic growth which differs among countries, (Robinson, 2006 and Narayan et al, 2007). There are studies showing that economic democracy has an positive effect (reinforces) on growth in transition economies but there is no relationship between political democracy and growth, it works indirectly through economic liberalization and improved democracy constrains the actions of corrupt officials, (Sandalcilar, 2013; Fidrmuc, 2003; Almeida and Ferreira, 2002; Rivera-Batiz, 1999; Kurzman et al, 2002).

The investment profile improves growth by creating a good environment that enhances the level of Foreign Direct Investment (FDI) flows to the host country. Countries with a greater scope of economic freedom register high growth in Gross Domestic Product (GDP) but such findings are mixed, (Busse and Groizard, 2008; Prochniak and Witkowski, 2013; Julilian et al, 2007; Haidar, 2012). The quality of regulation should be supported by the improved liquidity of financial markets, efficient regulatory policies and a greater scope of economic freedom.

Several studies support the view that the rule of law and strong legal systems are a pre-condition for growth in developing economies and that legal obstacles impede growth, corruption renders the law ineffective and weakens property rights which increases uncertainty, (Hasan, 2010 and Schmid and Higbee, 2004). However Wo-Cumings (2006) argues that legal traditions and institutions cannot determine the nature of the state and its role in the economy. Hence they do not determine the course of economic development, but this finding cannot be generalized as the study focused only on East Asia.

The other factors driving growth include capital inflows, human capital, investment, foreign direct investment, trade or economic openness, stock market liquidity, per Gross domestic product and good macroeconomic management, (Hill and Menon, 2013; Le, 2008; Coutinho, 2012; Chumacero and Fuentes, 2005; Gutierrez, 2005; Ndambiri et al, 2012; Tiwari and Mutascu, 2011; Rahman \& Salahuddin, 2010; Caporale et al, 2004; Shahbaz et al, 2008). While factors that retard growth include: remittances, high inflation, (Le, 2008; Coutinho, 2012; Rahman \& Salahuddin, 2010). There are studies which argue that remittances exert weak and positive impact on economic growth over the long term and they affect growth indirectly through consumption levels, savings and investment expenditure, (Catrinescu et al, 2006; Leon-Ledesma, 2004; Lucas, 2005). The long term impact is enhanced with the presence of credible economic policies and institutions. Total factor productivity was explained by exogenous technological shocks, terms of trade, price of investment goods relative to consumption and distortions as explained by the share of fiscal expenditures, the direction of causality between investment and growth is bidirectional, and productivity improves as human development (expenditure on health and education) improves, (Chumacero and Fuentes, 2005; Gutierrez, 2005; Ramirez et al, 1997). However, Flier et al (1999) argues that causality moves from stock market development to economic growth in less 
development countries while Liang and Reichert (2006) show that it is the other way round.

Trade reduces the productivity gap between the less developed and advanced regions despite the existence of innovative industries in the later. Productivity improves as a result of increased foreign competition and trade liberalization improves social welfare, (Muendler, 2002; Manni and Afzal, 2012; Tan, 2012; Shaheen et al, 2013, Asiedu, 2013; Dava, 2012; Bajona et al, 2010). Evidence also shows that there may be no connection between real GDP and trade liberalization and the connection can turn out to be negative if it exists. Growth rates may even slow down during episodes with free trade than under autarky. Liberalization works well with improved institutions like good regulatory policies on credit, labour and product markets, (Bajona et al, 2010; Biwott et al, 2013; Baliamoune-Luzt and Ndikumana, 2007). FDI is another key determinant of economic growth as described in literature. It acts as an important vehicle for the transfer of technology which contributes more to growth than domestic investment when working with a minimum threshold of human capital. A more developed financial system positively contributes to the process of technological diffusion associated with FDI, (Borensztein et al, 1998; Hermes and Lensink, 2003). This is however dismissed by Carkovic and Levine (2002) who argued that the exogenous component of FDI does not exert a robust, independent influence on growth.

The findings in literature are diverse and depend on the data and method of analysis used. There is no general consensus on the effect of institutional variables on growth using country specific data. Findings show that the effect of institutional variables can be positive, negative or there is no effect on growth. These findings suggest that more work still needs to be done considering a regional block particularly in an African context. There is still limited discussion on the SADC region on the role of institutions which leaves room for further analysis. This study contributes to the debate by using panel data approach and country level data within a regional framework. These countries share common principles and guidelines in their endeavor to attain growth. Thus the discussion on economic growth will be incomplete without considering the role of institutions, and also their interaction with other important determinants of growth.

\section{Methodological Issues: Data and Modeling}

\subsection{Description of Data}

The study used annual panel data for the period 1996-2010 being obtained from the World development Indicators (WDI) and international country risk guide (2014). The period is chosen based on data availability for 11 countries while others were excluded for lack of data and due to instability. Dynamic model was utilized which gains support from several studies, (Baltagi, 2005; Julilian et al, 2006; Catrinescu, 2006; Hsiao, 2003). Panel data analysis suggests that countries are heterogeneous, controls for heterogeneity and collinearity, gives more data points, brings more variability, gives more degrees of freedom, increases efficiency, allows study of speeds of adjustment to policy changes, allows us to discover and quantify effects that may not be detected using time series or cross sectional data.

\subsection{Description of Variables}

Economic growth $\left(G D P_{g}\right)=\mathrm{F}\left(G D P_{g, t-1}\right.$, Trade Openness, Inflation, Credit to Private Sector, Gross Fixed Capital

Formation, Financial openness, Domestic Credit by Banking sector, Savings ratio, Remittances, Human capital, Quality of institutions). These determinants of economic growth have been proved to be robust in literature and we discuss their measurements and expected effect on economic growth is in parenthesis [ ] below:

Trade openness (TO) is the sum of imports and exports of goods and services divided by gross domestic product [positive]; Inflation (IF) measures the annual percentage change in the cost to the average consumer of acquiring a basket of goods and services [negative]; Credit to Private Sector (CPS) as percentage of GDP represents financial resources provided to the private sector [positive]; Gross fixed capital formation (GFCF) consists of outlays in addition to fixed assets of the economy plus changes in the level of inventories [positive]; Financial openness (FDI) is the inflows of investment to acquire a lasting management interest in an economy other than that of the investor [positive]; Domestic credit by banking sector (DCB) represents credit provided by the banking sector to various sectors on a gross basis except central government [positive]; Savings ratio (SR) is act as withdrawal from circular flow of income which diminishes the rate of growth in the short term, it is the amount left after consumption expenditure. In the long term savings will act as a vehicle for sustained growth as more fixed capital is acquired [positive]; Remittances (Rem) is represented by current transfers by migrant employees and income earned by nonresident workers [ambiguous]; Investment in Human capital (HC) is given by the ratio of total enrolment to the population of the age group that officially corresponds to level of education [positive].

The key explanatory variable is quality of institutions which has been broken into five variables. Values closer to one are good as they mean good regulation quality, low corruption, strong law and order, more responsive government and low level of bureaucracy: Regulatory quality (RQ) is a measure of the risk to investments and investor protection 
[positive]; Law and order (RL) measures the strength and impartiality of legal system [positive]; Democratic accountability (VA) is a measure of how responsive the government is to its citizens[positive]; Corruption (CC) shows the level of corruption in the country [ambiguous]; Government effectiveness is measured by the level of bureaucracy in the government [positive].

\subsection{Dynamic model and Estimations}

The study used a dynamic linear model specified as follows:

$$
\mathrm{Y}_{i t}=\phi \mathrm{Y}_{i, t-1}+\mathrm{X}_{i t}^{\prime}+\eta_{i}+v_{t}+\mu_{i t}
$$

Where, $\mathrm{Y}_{i t}$ is represents economic growth, $\mathrm{X}_{i t}^{\prime}$ is a vector of exogenous variables, $\eta_{i}$ and $v_{t}$ represent country and

time specific effects respectively and $\mu_{i t}$ is the remainder of the error term. Firm effects are correlated with lagged

dependent variable $\left(\mathrm{Y}_{i, t-1}\right)$ which is serially uncorrelated with the disturbances and correlated with error term. The study employed Arellano and Bond (1991) GMM estimator which is better than Ordinary least squares (OLS) and within estimators which are biased upwards and downwards respectively. The study also tests for validity of instruments using Sargan tests and tests for autocorrelation. Estimations were conducted as follows: firstly, the basic model excluded the institutional quality variables which were then introduced one at a time to check their effect on growth and lastly a model with an interaction term was used to measure the indirect effect of institutional quality variables.

\section{Presentation and Discussion of Findings}

\subsection{Descriptive Statistics ${ }^{l}$}

Pairwise correlation analysis suggests that there were significant positive and negative association among variables. The growth in GDP had strong positive associations with trade openness and political stability \& absence of violence whilst it had negative association with domestic credit by banks and inflation. High correlation was recorded between domestic credit by banks and credit to private sector as such we dropped the former to avoid the problem of multicollinearity. The annual averages for determinants of growth were ranging between $0.6 \%$ (remittances) and $77 \%$ (trade openness) per annum, while institutional quality variables showed mean values between 0.35 and 0.72 . Inflation rate (standard deviation of 77.50) was the most volatile in the region compared to remittances (standard deviation of 1.04). Price stability differed during the period as some member states experienced high inflation rates than others. The receipts from migrant and non-resident employees were stable throughout the period. Most of the variables were normally distributed except for human capital, savings ratio and three institutional variables which had values of kurtosis of less than 3.

\subsection{Regression Analysis}

The study tested the null hypothesis that there is no auto correlation between our instruments and the error term. Table 1 shows that all the models used were correctly specified since there was no second order autocorrelation.

Table 1. Regression Results

\begin{tabular}{lllllllll}
\hline $\begin{array}{c}\text { Model } \\
\text { Variables }\end{array}$ & 1 & 2 & 3 & 4 & 5 & 6 & 7 & 8 \\
\hline$G D P_{g, t-1}$ & $-5.34 \mathrm{e}-15$ & $-3.34 \mathrm{e}-14$ & $4.53 \mathrm{e}-14$ & $3.58 \mathrm{e}-14$ & $-8.36 \mathrm{e}-15$ & $-4.30 \mathrm{e}-14$ & $3 \mathrm{e}-14$ & $2.94 \mathrm{e}-14$ \\
& {$[0.180]$} & {$[0.227]$} & {$[0.054]^{* *}$} & {$[0.03]^{*}$} & {$[0.665]$} & {$[0.327]$} & {$[0.049]^{* *}$} & {$[0.011]^{*}$} \\
CPS & $2.24 \mathrm{e}-15$ & $7.37 \mathrm{e}-15$ & $4.08 \mathrm{e}-15$ & $3.16 \mathrm{e}-15$ & $-7.04 \mathrm{e}-15$ & $3.16 \mathrm{e}-16$ & $3.84 \mathrm{e}-15$ & $2.46 \mathrm{e}-15$ \\
& $(0.61)$ & $(1.09)$ & $(0.69)$ & $(1.11)$ & $(0.88)$ & $(0.03)$ & $(0.33)$ & $(0.50)$ \\
GCFC & $-2.41 \mathrm{e}-15$ & $-5.14 \mathrm{e}-14$ & $-6.20 \mathrm{e}-14$ & $-3.22 \mathrm{e}-14$ & $6.38 \mathrm{e}-16$ & $2.07 \mathrm{e}-14$ & $-6.31 \mathrm{e}-14$ & $-8.83 \mathrm{e}-15$ \\
& $(0.38)$ & $(2.28)^{*}$ & $(1.72)^{* *}$ & $(1.81)^{* *}$ & $(0.04)$ & $(0.70)$ & $(2.07)^{*}$ & $(1.23)$ \\
$\mathrm{IF}$ & $-1.21 \mathrm{e}-15$ & $1.90 \mathrm{e}-14$ & $-1.59 \mathrm{e}-15$ & $-3.61 \mathrm{e}-15$ & $-7.31 \mathrm{e}-15$ & $5.66 \mathrm{e}-16$ & $4.09 \mathrm{e}-15$ & $-1.07 \mathrm{e}-15$ \\
& $(0.92)$ & $(1.10)$ & $(0.15)$ & $(0.36)$ & $(0.85)$ & $(0.06)$ & $(1.05)$ & $(0.47)$ \\
TO & $1.63 \mathrm{e}-14$ & $-2.03 \mathrm{e}-14$ & $-5.01 \mathrm{e}-15$ & $-2.29 \mathrm{e}-14$ & $5.28 \mathrm{e}-15$ & $-4.74 \mathrm{e}-14$ & $-2.60 \mathrm{e}-14$ & $6.32 \mathrm{e}-15$ \\
& $(2.69)^{*}$ & $(2.32)^{*}$ & $(0.92)$ & $(2.27)^{*}$ & $(0.49)$ & $(2.32)^{*}$ & $(1.85)^{* *}$ & $(1.88)^{* *}$ \\
FDI & $-7.34 \mathrm{e}-15$ & $4.87 \mathrm{e}-14$ & $-1.02 \mathrm{e}-14$ & $-3.70 \mathrm{e}-14$ & $-2.66 \mathrm{e}-14$ & $2.11 \mathrm{e}-15$ & $-5.81 \mathrm{e}-14$ & $-4.10 \mathrm{e}-16$ \\
\hline
\end{tabular}

\footnotetext{
${ }^{1}$ Results tables withheld, they can be provided by the author upon request
} 


\begin{tabular}{|c|c|c|c|c|c|c|c|c|}
\hline & $(1.81)^{* *}$ & $(1.24)$ & $(0.42)$ & $(1.39)$ & $(1.38)$ & $(0.09)$ & $(1,67)^{* *}$ & $(0.02)$ \\
\hline $\mathrm{HC}$ & $\begin{array}{l}-1.33 \mathrm{e}-14 \\
(1.88)^{* *}\end{array}$ & $\begin{array}{l}-1.98 \mathrm{e}-15 \\
(0.09)\end{array}$ & $\begin{array}{l}2.31 \mathrm{e}-14 \\
(1.25)\end{array}$ & $\begin{array}{l}1.96 \mathrm{e}-14 \\
(1.29)\end{array}$ & $\begin{array}{l}5.14 \mathrm{e}-14 \\
(1.88) * *\end{array}$ & $\begin{array}{l}4.39 \mathrm{e}-14 \\
(1.90)^{* *}\end{array}$ & $\begin{array}{l}-1.84 \mathrm{e}-14 \\
(0.71)\end{array}$ & $\begin{array}{l}-6.01 \mathrm{e}-15 \\
(1.01)\end{array}$ \\
\hline Rem & $\begin{array}{l}-2.06 e-14 \\
(0.17)\end{array}$ & $\begin{array}{l}-4.38 \mathrm{e}-13 \\
(0.79)\end{array}$ & $\begin{array}{l}9.34 \mathrm{e}-14 \\
(0.21)\end{array}$ & $\begin{array}{l}6.88 \mathrm{e}-14 \\
(0.33)\end{array}$ & $\begin{array}{l}5.35 \mathrm{e}-13 \\
(1.56)\end{array}$ & $\begin{array}{l}7.32 \mathrm{e}-13 \\
(1.71)^{* *}\end{array}$ & $\begin{array}{l}-1.96 \mathrm{e}-13 \\
(0.54)\end{array}$ & $\begin{array}{l}6.77 \mathrm{e}-14 \\
(0.79)\end{array}$ \\
\hline SR & $\begin{array}{l}5.87 \mathrm{e}-15 \\
(1.21)\end{array}$ & $\begin{array}{l}-2.41 \mathrm{e}-14 \\
(1.58)\end{array}$ & $\begin{array}{l}-5.22 \mathrm{e}-14 \\
(2.23)^{*}\end{array}$ & $\begin{array}{l}-2.25 \mathrm{e}-14 \\
(1.17)\end{array}$ & $\begin{array}{l}-1.72 \mathrm{e}-14 \\
(0.97)\end{array}$ & $\begin{array}{l}-6.75 \mathrm{e}-14 \\
(1.65)^{* *}\end{array}$ & $\begin{array}{l}-3.79 \mathrm{e}-14 \\
(1.76)^{* *}\end{array}$ & $\begin{array}{l}-2.03 e-14 \\
(2.14)^{*}\end{array}$ \\
\hline Constant & $\begin{array}{l}-9.86 e-14 \\
(0.32)\end{array}$ & $\begin{array}{l}5.90 \mathrm{e}-12 \\
(2.62)^{*}\end{array}$ & $\begin{array}{l}2.38 \mathrm{e}-12 \\
(1.56)\end{array}$ & $\begin{array}{l}3.65 \mathrm{e}-12 \\
(2.88)^{*}\end{array}$ & $\begin{array}{l}3.33 \mathrm{e}-12 \\
(1.35)\end{array}$ & $\begin{array}{l}1.87 \mathrm{e}-12 \\
(0.94)\end{array}$ & $\begin{array}{l}2.74 \mathrm{e}-13 \\
(0.18)\end{array}$ & $\begin{array}{l}-4.18 \mathrm{e}-13 \\
(1.36)\end{array}$ \\
\hline VA & & $\begin{array}{l}1.32 \mathrm{e}-13 \\
(0.12)\end{array}$ & & & & & & \\
\hline PV & & & $\begin{array}{l}6.03 \mathrm{e}-12 \\
(2.02)^{*}\end{array}$ & & & & & \\
\hline GE & & & & $\begin{array}{l}-2.38 \mathrm{e}-12 \\
(2.17)^{*}\end{array}$ & & & & \\
\hline RQ & & & & & $\begin{array}{l}-3.45 \mathrm{e}-12 \\
(1.48)\end{array}$ & & & \\
\hline RL & & & & & & $\begin{array}{l}1.88 \mathrm{e}-13 \\
(0.06)\end{array}$ & & \\
\hline $\mathrm{CC}$ & & & & & & & $\begin{array}{l}-2.28 \mathrm{e}-13 \\
(0.21)\end{array}$ & \\
\hline FDIPV & & & & & & & & $\begin{array}{l}-4.44 \mathrm{e}-14 \\
(1.74)^{* *}\end{array}$ \\
\hline $\begin{array}{l}\mathrm{N} \\
\text { Auto } \\
\text { correlation }\end{array}$ & 108 & 68 & 68 & 68 & 68 & 68 & 68 & 108 \\
\hline z-test 1 & $\begin{array}{l}-1.9374 \\
{[0.0527]}\end{array}$ & $\begin{array}{l}2.5329 \\
{[0.0113]}\end{array}$ & $\begin{array}{l}-2.5419 \\
{[0.0110]}\end{array}$ & $\begin{array}{l}0.7276 \\
{[0.4669]}\end{array}$ & $\begin{array}{l}-4.5908 \\
{[0.0000]}\end{array}$ & $\begin{array}{l}2.3901 \\
{[0.0168]}\end{array}$ & $\begin{array}{l}-0.5324 \\
{[0.5944]}\end{array}$ & $\begin{array}{l}-3.4257 \\
{[0.0006]}\end{array}$ \\
\hline z-test 2 & $\begin{array}{l}-1.2638 \\
{[0.2063]}\end{array}$ & $\begin{array}{l}1.3336 \\
{[0.1823]}\end{array}$ & $\begin{array}{l}0.5189 \\
{[0.6039]}\end{array}$ & $\begin{array}{l}-0.0293 \\
{[0.9767]}\end{array}$ & $\begin{array}{l}-1.5584 \\
{[0.1191]}\end{array}$ & $\begin{array}{l}-0.1941 \\
{[0.8461]}\end{array}$ & $\begin{array}{l}-1.3391 \\
{[0.1805]}\end{array}$ & $\begin{array}{l}1.498 \\
{[0.1314]}\end{array}$ \\
\hline
\end{tabular}

Notes: The figures in parenthesis ( ) are the z-statistics for the model. * and ** represent significance at 5\% and $10 \%$ level respectively. Figures in [ ] are the probability values. Robust estimator was used after one step estimator and autocorrelation tests were done.

The estimated speed of adjustment towards the target level of growth was near zero hence there was instant adjustment to the desired level of growth. Model 1 shows that trade openness, financial openness and human capital were important in explaining economic growth. The introduction of institutional variables, models 2 to 7 , changed the results by improving the significance levels of three more additional explanatory variables: gross fixed capital formation, savings ratio and remittances. An interaction between financial openness and Political Violence was significant. Discussions for significant variables are as follows:

\subsubsection{Institutional Variables}

Political stability and the absence of violence had a significant positive effect on growth in SADC region while government effectiveness had a negative effect on growth. Our findings were as hypothesized showing that more future growth is expected as member states work towards internal and regional peace and stability. The absence of internal conflicts, ethnic tensions in the region contributed positively to growth prospects. Bureaucracy was high in the region which had an effect of retarding growth and our findings are consistent with studies by Papaconstantinou et al (2013) and Catrinescu et al (2006). The other four institutional variables did not directly affect the rate of growth in the region. An important observation in our findings is that voice and accountability was positive and insignificant (Sandalcilar (2013)) but produced an adverse effect on growth by working indirectly through gross fixed capital formation and trade openness which is consistent with Robinson (2006); Regulation Quality worked through human capital in enhancing regional growth thus increased human capital flows are beneficial when supported by a better investment profile; Rule of Law worked through savings ratio, and trade openness in reducing growth but enhanced growth by working indirectly through human capital and remittances flowing to member states. Thus strong legal institutions enhance growth through attracting more human capital and remittances as confidence levels increases in the recipient country. The level of savings increases as such less funds will be available for spending which acts as a withdrawal from the circular flow of income but this may be temporary. The effect, on growth, of legal systems through savings is dependent upon the level of the marginal propensity to save (MPS). The smaller the MPS, then the smaller is the impact of savings 
ratio on growth. The level of corruption reduces growth as it works, negatively, through gross fixed capital formation, trade openness, financial openness, remittances and savings. Thus corruption has a significant indirect negative effect on growth by influencing more variables as expected, (Aidt, 2009 and Farida \& Ahmadi-Esfahani, 2006). High corruption levels are not favorable in the SADC region which supports views that it increases uncertainty and the cost of doing business. Corruption had an effect of reducing both physical and human capital in the region. Findings suggest that an important role was played by the quality of institutions in the SADC region to enhance or retard growth. Thus more attention is needed in this aspect by all member states.

\subsubsection{Marginal effects of Institutions on Growth}

The most notable result is that with the introduction of an interaction term between financial openness and political violence (FDI*PV), the lagged variable for growth turned out to be positive and significant, trade openness now had a positive effect as expected while savings ratio remained negative. The other variables were not significant though some changed signs. The interaction term was significantly negative suggesting that the member states need to attain a certain level of financial openness and low levels of political violence to boost growth. Thus good government stability, low levels of internal and external conflict and ethnic tensions are vital to support growth through high levels of financial openness. The low levels of political violence assist in transmitting gains from financial openness into growth potential for the SADC region. If the region becomes unstable then growth will subside but if good institutions are put in place then more flows of foreign investment are attracted which boost growth through the multiplier process. Member states will experience growth due to FDI flows as they put in place good quality institutions. Political instability can be a source of failure by SADC countries in attracting enough FDI flows to boost growth.

\subsubsection{Determinants of Economic Growth}

The introduction of institutional quality variables resulted in gross fixed capital formation having a negative effect on growth which is inconsistent with the expected positive behavior as in Shaheen et al (2013) and Asiedu (2013). The explanation can be that the holding of stocks of goods by firms to meet temporary fluctuations in business had detrimental effects as firms had more of their resources tied up in stock. The other explanation is that poor institutional indicators rendered the buildup of fixed assets to be unfruitful. Thus good quality institutions are vital to enhance growth as they support the increase in stocks of fixed assets otherwise their absence can be detrimental.

Consistent with studies, (see Asiedu, 2013; Mercan et al, 2013; and Tan, 2012), trade openness had a positive and significant effect on growth before the inclusion of institutions in the model. This showed that as the countries in SADC opened up their economies the rate of growth increased significantly. However, this result can be misleading without considering the quality of institutions as the same variable turned out to be negative with their introduction. Findings suggest that the impact of trade on growth can be fully understood by incorporating the quality of institutions. Thus openness becomes less beneficial to growth the more governments becomes unstable coupled with conflicts, the more bureaucratic the systems in member states becomes, the more democratic accountability and investment profile falls within the region. Thus trade openness is very sensitive to the strength of institutions in the region.

Financial openness had a negative and significant effect on growth even without taking into consideration the effect of institutions which is consistent with studies by Shaheen et al (2013) and Asiedu (2013). This means the FDI flows have failed to boost growth within the region possibly due to the lack of an enabling environment like supporting institutions. On the greater part the coefficient of FDI remained negative and insignificant with the introduction of institutions in the model. The level of corruption had an effect of reinforcing the adverse effect of financial openness which supports the assertion that poor quality of institutions retard growth as countries register low volumes of foreign investment. For example findings suggest that the more democratic the governments are, and the more countries provide an environment with rule of law then the more growth is supported by financial openness.

The more students are enrolled to secondary schools, a proxy for human capital, the lower is the rate of growth in the region. This result is not supportive to our expectations but instead confirms the findings by Coutinho (2012) though our study used a different measure of human capital. However, the provision of quality institutions resulted in growth being enhanced by increases in human capital. Findings show that the absence of internal and external strife, existence of government stability, improvements in bureaucratic quality, improved investment profiles and the existence of rule law will help boost growth through the buildup of human capital in the regional block. Thus failure to create an enabling environment by putting good quality institutions may defeat the purpose of investing in human capital to enhance growth in the region.

The savings ratio as expected had a positive effect on growth, before introduction of institutions, though being insignificant. The negative effect of savings on growth is revealed by introducing institutional quality. The more people save in the short term then the less is spend on consumption which reduces the multiplier effect and hence the level of growth falls. In the long term growth is expected to improve as the savings are converted into fixed capital. 
Alternatively, in the short term, if savings fall below investment, then aggregate demand increases which boost growth but in the long term the reverse happens as growth will fall. Thus savings are beneficial to the economy in the future if they end up being converted into increased investment expenditure. Findings show that institutions have an important indirect effect on the contribution of savings to growth in the SADC region. In this study the effect of savings was negative showing that institutions help create a better environment for savings to be converted into meaningful fixed capital investments in the long term which helps in boosting growth in the region. Thus failure to provide supporting institutions will result in little savings being converted into investment expenditure which retards growth and this finding has huge policy implications.

\section{Conclusions and Implications}

The study mainly focuses on economic growth in SADC to examine the role of institutional variables; determine the key drivers and to find out the strength of the marginal effects of institutional quality. This was motivated by failure in literature to close the discussion on the determinants of growth in a regional bloc and the absence of sufficient evidence to capture the contribution of the quality of institutional factors on growth. The study provides strong evidence that institutional quality creates an enabling environment suitable for enhancing economic growth in the region. Improving government effectiveness and reducing levels of political violence is more beneficial within the region. It is vital for member states to reduce levels of bureaucracy and avoid the rise of internal conflicts which can hinder growth. The stability of government, absence of conflicts in the region and improved government effectiveness have a direct effect on growth. The study also suggests that good quality institutions have an indirect impact on economic growth as they work through trade openness, gross fixed capital formation, financial openness, human capital and savings ratio. These variables are effective if better institutions are provided by the member states otherwise growth is retarded once institutions fail to offer the needed support. The increase in human capital, rise in savings accumulation and reduction in corruption strongly support growth initiatives thus it is of paramount importance for member states to put in place improvements in this area. The strength of corruption in reducing growth should not be underestimated as our findings confirmed its indirect influence by working through most of the variables. Training of human capital alone cannot be effective without putting in place a good environment for investors. Member states should create incentives for new investors and create confidence in the environment. In the event that the rule of law is compromised the study has shown that the level of savings would deteriorate which affects the capacity to generate fixed stocks of capital in the future. Thus better quality institutions improve the positive effect of human capital accumulation and savings on economic growth in the long term. Low levels of political violence are vital for the region to benefit from high inflows of foreign investment otherwise these inflows will become ineffective. The study provides evidence that credit to private sector, remittances (see Catrinescu et al (2006)) and inflationary pressures have no significant contribution to growth even in the presence of good institutions. Findings in this study support the idea that failure by SADC states to realize growth supported by trade openness, financial openness, increased investment in human capital and high savings is their failure to put in place better quality institutions. Thus implications of this study are that any reforms meant to boost growth should first and foremost focus on creating good quality institutions. Institutions have proved to have both direct and indirect effect on growth and specifically growth using attraction of foreign investment cannot be realized until the region is free from ethnic tensions, internal and external conflict and government instability. The use of the generic determinants of the growth alone gives an incomplete story within the SADC region. These variables are necessary but not sufficient to explain economic growth. The findings in this study warrant further research to examine the role of institutions using country level data and regional data for both developing and developed countries to allow for comparisons.

\section{References}

Acemoglu, D., \& Verdier, T. (1998). Property Rights, Corruption and the Allocation of Talent: A General Equilibrium Approach, Economic Journal, 108(450), 1381-1403. http://dx.doi.org/10.1111/1468-0297.00347

Acemoglu, D., Simon, J., \& James, A. R. (2001).The colonial origins of comparative development: an empirical investigation, American Economic Review, 91, 1369-1401. http://dx.doi.org/10.1257/aer.91.5.1369

Acemoglu, D., \& Johnson, S. (2005). Unbundling Institutions, Journal of PoliticalEconomy, 113(5), 949-995. http://dx.doi.org/10.1086/432166

Aidt ,T. S. (2009). Corruption, institutions and economic development, Faculty of economics, University of Cambridge.

Alesina, A., Sule, O., Nouriel, R., \& Phillip, S. (1996). Political instability and economic growth. Journal of Economic Growth, 1(2), 189-211. http://dx.doi.org/10.1007/BF00138862

Almeida, H., \& Ferreira, D. (2002). Democracy and the Variability of Economic Performance, Economics and Politics, 14(3). http://dx.doi.org/10.1111/1468-0343.00107

Aron, J. (2000). Growth and Institutions: A review of the evidence, The World Bank Research Observer, 15(1), 99-135. 
http://dx.doi.org/10.1093/wbro/15.1.99

Arrellano, M., \& Bond, S. (1991) Some tests of specification for panel data: Monte Carlo evidence and an application to employment equations, Review of Economic Studies, 58,277-297. http://dx.doi.org/10.2307/2297968

Asiedu, E., \& Freeman, J. (2009). The effect of corruption on investment growth: Evidence from firms in Latin America, Sub Saharan Africa and Transition economies, Review of Development Economics, 13(2). Retrieved from: onlinelibrary.wiley.com/doi/10.1111/j.1467-9361.2009.

Asiedu, M. K. (2013). Trade liberalization and growth: The Ghanaian experience, Journal of economics and sustainable development, 4(5).

Bajona, C., Kehoe, T. J., \& Ruhl, K. J. (2010). Trade liberalization, growth and productivity, University of Nottingham, UK, unpublished paper.

Baliamoune-Luzt, M., \& Ndikumana, L. (2007). The growth effects of openness to trade and the role of institutions: New evidence from African countries, University of Massachusetts, Working paper 2007-05.

Baltagi, B. H. (2005). Econometric analysis of panel data, $3^{\text {rd }}$ edition, John Wiley \& Sons, Ltd.

Barro, \&Robert, J. (1991). Economic Growth in a Cross Section of Countries, Quarterly Journal of Economics, 106(2), 407-43. http://dx.doi.org/10.2307/2937943

Barro, R. J., \& Sala-i-Martin, X.Economic Growth, 2nd edition, MIT Press, Cambridge, 2004.

Bhupatiraju, S., \& Verspagen, B. (2013). Economic development, growth, institutions and geography, United Nations University - Merit Working paper series, 16.

Biwott, P. K., Moyi, E. D., \&Khainga D. (2013).Trade Liberalization and Economic Growth: The Role of Regulatory Policies. Journal of World Economic Research, 2(3), 2013, 45-57. http://dx.doi.org/10.11648/j.jwer.20130203.13

Borensztein, E., De-Gregorio, J., \& Lee, J. W. (1998). How does foreign investment affect economic growth? Journal of international economics, 45(1998), 115-135. http://dx.doi.org/10.1016/S0022-1996(97)00033-0

Busse, M., \& Groizard, J. L. (2008). Foreign direct investment, regulations and growth, The world economy, Blackwell publishing limited, UK.

Caporale, G. M., Howells, P. G., \& Soliman, A. M. (2004). Stock market development and economic growth: the causal link, Journal of Economic Development, 29(1).

Carkovic, M., \& Levine, R. (2002). Does foreign direct investment accelerate economic growth? University of Minnesota.

Catrinescu N, Leon-Ledesma, M., Piracha, M., \& Quillin, B. (2006). Remittances, Institutions and Economic Growth, Institute for the study of labour (IZA). Discussion paper,2139.

Commander, S., \& Nikoloski, Z. (2010). Institutions and economic performance: What can be explained? European bank for reconstruction and development, working paper, 121 .

Cooray, A. (2008). Economic growth and the size and quality of the government, School of economics, University of Tasmania. Retrieved from: https://www.aeaweb.org/annual_mtg_papers/2008/2008_519.pdf.

Coutinho L (2012). Determinants of growth and inflation in Southern Mediterranean countries, MEDPRO Technical report No. 10/March 2012. Retrieved from: http://www.Medpro-foresight.eu

Chumacero, R. A., \& Fuentes, J. R. (2005). On the determinants of Chilean economic growth, Central bank of Chile, Santiago.

Dava (2012). Trade liberalization and economic growth in SADC: A difference in difference analysis, IESE conference paper, 8.

Demetraides, P., \& Law, S. H. (2004). Finance, institutions and economic growth, University of Leicester, Working paper.

Dixit, A. (2004).Lawlessness and Economics: Alternative Institutions of Governance,Princeton: Princeton University Press, Chapter 1. Available at http://pup.princeton.edu/titles/7729.html.

Drury, A. C., Krieckhaus, J., \& Lusztig, M. (2006). Corruption, democracy and economic growth, International political science review, 27(2). http://dx.doi.org/10.1177/0192512106061423

Farida,M., \& Ahmadi-Esfahani, F. (2006). Corruption and economic growth in Lebanon, Discipline of agricultural and resource economics, University of Sydney, Australia.

Firdmuc, J. (2003). Economic reform, democracy and growth during post-communist transition, European Journal Of 
Political Economy, 19(2003), 583-604. http://dx.doi.org/10.1016/S0176-2680(03)00010-7

Flier, R. K., Hanousek, J., \& Campos,N. F. (1999). Do stock market promote economic growth? Working Paper,267.

Glaeser, E. L., La-Porta, R., Lopez-de-Silanes, F., \& Shleifer, A. (2004). Do institutions cause growth? NBER Working paper, 10568. Retrieved from: http://www.nber.org/papers/w10568

Goel, R. K. (2011). Determinants of economic growth in the BRIC countries, Development Research Working Paper Series.

Gutierrez, M. A. (2005). Economic growth in Latin America: the role of investment and other growth sources, CEPAL, Economic Development Division, Santiago Chile.

Gyimah-Brempong, K. (2001). Corruption, economic growth and income inequality in Africa, Economics of Governance, 3, 183-209.

Gylfason, \& Hochreiter (2008). Determinants of economic growth: A comparative analysis of Estonia and Georgia, presented at the conference on Economic transformation of Central and Eastern European countries, Vilnius.

Haidar, J. I. (2012). The impact of business regulatory reforms on economic growth, Journal of The Japanese and International Economies,26(2012), 285-307. http://dx.doi.org/10.1016/j.jjie.2012.05.004

Hasan, L. (2010). Rule of law, legal development and economic growth: Perspectives for Pakistan, Pakistan Institute of Development Economics. Retrieved from: http://ssrn.com/abstract=1685132.

Hassan et al (2011).Rule of law, legal development and economic growth: Perspectives for Pakistan, Pakistan Institute of Development Economics.

Heckelman, J. C., \& Powell, B. (2008). Corrption and the institutional environment for Growth, Department of Economics, Suffolk University, Working paper.

Hermes, N., \& Lensink, R. (2003). Foreign direct investment, financial development and economic growth, The Journal of development studies,38.http://dx.doi.org/10.1080/00220380412331293707

Hill, H., \& Menon, J. (2013). Cambodia: Rapid growth with institutional constraints, ADB economics, working paper series.

Hodge, A., Shankar, S., Rao, D. S., \& Duhs, A. (2009). Exploring the links between corruption and growth, School of economics, University of Queensland, Discussion Paper, 392.

Hsiao, C. (2003).Analysis of Panel Data (Cambridge University Press, Cambridge). http://dx.doi.org/10.1017/CBO9780511754203

International country risk guide. (2014). Political risk services, Retrieved from: http://www.info.worldbank.org/governance/wgi/pdf/PRS

Julilian, H., Kirkpatrick, C., \& Parker, D. (2007). The impact of regulation on economic growth in development countries: A cross-country analysis, http://www.researchgate.net/publication/4899298_The_Impact_of_Regulation_on_Economic_Growth_in_Develop ing_Countries_A_Cross-Country_Analysis/file/d912f50effaa09b155.pdf.

Kurzman, C., Werum, R., \& Burkhart, R. E. (2002). Democracy'e effect on economic growth: A pooled time series analysis, 1951-1980, Studies in Comparative International Development, Springer, 37(1),3-33. http://dx.doi.org/10.1007/BF02686336

Lal, D. (1998). Institutional development and economic growth, University of California, Working Paper,782.

Le, T. (2008). Trade, Remittances, Institutions and Economic Growth, school of economics, University of Queensland.

León-Ledesma, M., \& Matloob, P. (2004). International Migration and the Role of Remittances in Eastern Europe, International Migration, 42(4), 65-84. http://dx.doi.org/10.1111/j.0020-7985.2004.00295.x

Lucas, R., Jr, E. (1988). On the Mechanics of Economic Development, Journal of Monetary Economics, 22, 3-42.

Lucas, R. E. B. (2005). International Migration and Economic Development, Stockholm: Expert Group on Development Issues, Swedish Ministry for Foreign Affairs.

Liang, H. Y., \& Reichert, A. (2006). The relationship between economic growth and banking sector development, Banks and Bank Systems, 1(2), 2006.

Manni, U. H., \& Afzal, M. N. (2012). Effect of trade liberalization on economic growth of developing countries: A case of Bangladesh economy, Journal of Business, Economics and Finance, 1(2).

Maria-Carmen (2009). Government effectiveness, education, economic development and well-being: Analysis of 
European countries in comparison with United States and Canada, Applied econometrics and international development, 9-1(2009).

Mauro, P. (2004). The persistence of corruption and slow economic growth, IMF staff papers, 5l(1).

Mauro, P.(1995).Corruption and Growth, Quarterly Journal of Economics, 110(3),681-712.

Mercan, M., Gocer, I., Bulut, S., \& Dam, M. (2013). The effect of openness on economic growth for BRIC-T Countries: Panel data analysis, Eurasian Journal of Business and Economics, 6(11), 1-14.

Mo, P. H. (2001). Corruption and Economic Growth Journal of Comparative Economics, 29, 66-79. http://dx.doi.org/10.1006/jcec.2000.1703

Muendler, M. A. (2002). Essays on International trade, Growth and Finance, University of California, Berkeley, Unpublished $\mathrm{PhD}$ thesis.

Narayan, P. K., Narayan, S., \& Smyth, R. (2007). Does democracy facilitate economic growth or does economic growth facilitate democracy? An ampirical study of Sub Saharan Africa, Department of economics, Monash University, Discussion Paper.

Ndambiri, H. K, Ritho, C., Ng'ang'a, S. I., Kubowon, P. C., Mairura, F. C., Nyangweso, P. M., Muiruri, E. M., \& Cherotwo, F. H. (2012). Determinants of economic growth in Sub Saharan Africa: a panel data approach, International Journal of Economics and Management Sciences, 2(2), 18-24.

North, D. C. (1990). Institutions, Institutional Change and Economic Performance, Cambridge: Cambridge University Press. http://dx.doi.org/10.1017/CBO9780511808678

Papaconstantinou, P, Tsagkanos, A. G., \& Siriopoulos, C. (2013). How bureaucracy and corruption affect economic growth and convergence in the European Union? The case of Greece, University of Patras. Retrieved from: http://www.idec.gr/.../corruption\%20CONFERENCE/How\%20Bureaucracy

Podobnik, B, Shao, J., Njavro, D., Ivanov, P., \& Stanley, H. E. (2008). Influence of corruption on economic growth rate and foreign investment, The European physical Journal, 63, 547-550. http://dx.doi.org/10.1140/epjb/e2008-00210-2

Prochniak, M., \& Witkowski, B. (2013). The analysis of the Impact of regulatory environment on the pace of economic growth of the world countries according to the Bayesian Model averaging, NDP Working Paper, 165.

Rahman, M. M., \& Salahuddin, M. (2010). The determinants of economic growth in Pakistan: Does stock market development play a major role? Economic issues, 15(2).

Ramirez, A., Ranis, G., \& Stewart, F. (1997). Economic growth and human development, Economic growth center, Yale University, Center Discussion Paper, 787.

Ricardo, D. (1951). On Foreign Trade. in Sraffa,P. and Dobb,M.H. (eds.).The Works andCorrespondence of David Ricardo, 1, Cambridge, UK: Cambridge University Press.

Rivera-Batiz, F. L. (1999). Democracy, governance and economic growth: Theory and evidence, Department of economics, Columbia university, New York.

Robinson, J. A. (2006). Economic development and democracy, Annual Review of Political Science,9,503-27. http://dx.doi.org/10.1146/annurev.polisci.9.092704.171256

Rodrik, D., (1997).TFPG Controversies, Institutions and Economic Performance in East Asia, National Bureau of Economic Research Working Paper,5914.

Rodrik, D, Arvind, S., \& Francesco, T. (2004).Institutions rule: the primacy of institutions over geography and integration in economic development, Journal of Economic Growth, 9, 131-165. http://dx.doi.org/10.1023/b:joeg.0000031425.72248.85

Romer, P. M. (1990). Human Capital and Growth. Paper presented at the Carnegie-Rochester Conference on Economic Policy, Rochester, New York.

Sala-i-Martin, X. X. (2002). 15 Years of New Growth Economics: What Have We Learnt? Central Bank of Chile Working Paper, 172, 22. http://dx.doi.org/10.2139/ssrn.320765

Sandalcilar, A . R. (2013). Democracy and growth, American Journal of Contemporary Research, 3(1).

SADC (2011). Desk assessment of the regional indicative strategy development plan 2005-2010, SADC council, November 2011. Retrieved from:http://www.sadc.int/documents-publications/show /Regional_Indicative_Strategic_Development_Plan_Desk_Assessment.pdf. 
Schmid, F. A., \& Higbee, J. (2004). Rule of law and economic growth, International economic trends, Federal Reserve Bank of St Louis.

Shahbaz, M., Ahmed, N., \& Ali, L. (2008). Stock market development and economic growth: Ardl causality in Pakistan, International research Journal of finance and economics, 14. Retrieved from: http//:www.eurojournals.com/finance.htm

Shaheen, S, Ali, M. M., Kauser, A., \&Bashir, F. (2013). Impact of trade liberalization on economic growth in Pakistan, Interdisciplinary Journal of Contemporary Research in Business, 5(5). Retrieved from: http://www.ijcrb.webs.com

Smith, A. (1986). [1776]. The Wealth of Nations. London: Penguin Books.

Solow, R. M. (1956). A contribution to the theory of economic growth, Quarterly Journal of Economics, 70(1), 65-94, http://dx.doi.org/10.2307/1884513

Tan-C, J. K. (2012). International trade and economic growth: Evidence from Singapore, Columbia University, Masters thesis.

Tebaldi, E., \& Elmslie, B. (2008). Institutions, innovations and economic growth, Journal of Economic Development, $33(2)$.

Tiwari, A. K., \& Mutascu, M. (2011). Economic growth and FDI in Asia: A panel data approach, Economic Analysis and Policy, 41(2).

Venard, B. (2013). Institutions, corruption and sustainable development, Economics Bulletin, 33(4).

Wo-Cumings, M. (2006). Rule of law, legal traditions and economic growth in East Asia, World institute of development, Research paper, 53.

\section{(cc) BY}

This work is licensed under a Creative Commons Attribution 3.0 License. 